I. V. Danilova, A. V. Rezepin

\title{
COORDINATION OF FEDERAL AND REGIONAL ACTIONS OF STABILIZATION POLICY FOR HETEROGENEOUS ECONOMIC AREA ${ }^{1}$
}

The purpose of this article is to discuss conceptual approaches to the development of stabilization policy in federal countries. In this article, the authors have justified the need for a regional component in the mechanism of the domestic price level stabilization policy and systemized relevant factors that have a significant impact on the spatial outcome of stabilization policy. The article proposes a method of determining the spatial zones of high, medium and low "susceptibility" to measures of stabilization policy center, and includes the following: 1) analysis of regional price manageability background; 2) sensitivity study of the regional banking system to a change in central bank policy; 3) elasticity analysis of the reaction of the popula-

${ }^{1}$ @ Danilova I. V., Rezepin A. V. Text. 2014. 
tion and business in the region to change the activity of the regional banking system. The authors have formulated the principles of coordination of actions between the federal center and the regions in the implementation of stabilization policies that allow to take into account differences between the regions in response to the changes made in federal policy. The paper has substantiated the system of performance indicators that measures anti-inflationary policy and also takes into account the heterogeneity of economic space of the Russian Federation in the context of the "direct" and "conjugate" effects on the central regions. Theoretical position application and output indicators, which are outlined in this article allow building a system of coordination and interaction between the federal center and the regions and thus ensuring the effectiveness of stabilization policies and non-inflationary development of Russia.

Keywords: stabilization policy, coordination of economic policies, the heterogeneity of economic space; inflation targeting

The instability of market systems necessitates deepening studies of stabilization of economic policy as a deliberate action on mitigation of economic fluctuations and maintaining the level and growth rate of socio-economic parameters. For Russia, which has a complex territorial structure as well as high heterogeneity of economic space, the stabilization measures of the federal center can cause a variety of real consequences. The traditional direction of stabilization policies aimed at cushioning the adverse economic "shocks" in the period of the recession crisis, at the level of the territories of Russian Federation can lead to unplanned changes (decrease of the multiplier impact of regulatory instruments, pro-cyclical effects, and increase of regional differentiation). The negative effects of stabilization policy in some regions can exceed the benefits of progress that was reached in others. Abstracting from the differentiation of regional socio-economic conditions explains the poor performance of regulatory measures.

In theory, the stabilization policy is the impact of government on economic activity, aimed at mitigating the cyclical downturns and the maintenance of socio-economic parameters of the official exchange rate at a given level (in terms of GDP growth, unemployment, inflation, etc.). The level of socio-economic parameters in the framework of the official exchange rate is defined as targeted guidelines. The long-term focus of stabilization policy is to achieve rather sustainable strategic options. For developed countries, characterized by a stable monetary system and a stable price level, the priority is targeting the level of employment, and for developing countries - targeting the inflation level.

In the works of J. Tinbergen [16], J. Sachs [14], O. Blanchard [11], P. Velfens [17], S. Moiseev [5], S. Drobyshevskiy [3], J. Alexandrov [1], A. Sukharev [8] structural elements of the stabilization policy were first developed, the general logic of implementing them includes the following steps: 1 ) government choice of the ultimate goal as well as a key target for stabilization (GDP, inflation, or other), 2) fixation of quantification targets, 3) the specification of necessary tools, 4) predicting the impact of the chosen tool on the target and definition of the scope, parameters, and the intensity of the regulatory impact, 5) determination of the results and analysis of deviations of actual performance from the target, 6) identification of constraints and development of corrective measures to minimize the costs of stabilization actions. The mechanism of stabilization is considered aggregated and does not include the transmission of the regulatory impact of the center to the regions (territorial units) $[4,13]$. However, in our opinion, in countries with high heterogeneity of economic space, such as Russia, the mechanism of stabilization policy is mostly defined by the regional transmission components. With 85 territorial units of Russian Federation that differ greatly in socio-economic circumstances, it is reasonable legitimately to predict mismatch targets and the actual effects of federal stabilization actions at the regional level.

In the circumstances of sustainable price background, which recorded a policy of "inflation targeting" which was implemented in 2003, it is possible to implement the strategic priorities in the Russian part of the modernization and diversification of the economy, as well as the transition to innovative development. It is our opinion that macro-and meso-economic impact of longterm non-inflationary rate of development in the Russian Federation is primarily determined by the formation of the channels of decision transmission from the federal center to the regional level.

We believe that in the price stabilization mechanism structure is appropriate to define federal and regional components. Federal component has the following regulatory decisions: the choice of quantitative parameters of the target, assessment of the appropriate tool use limits, generating the initial monetary impulse and change the operating 


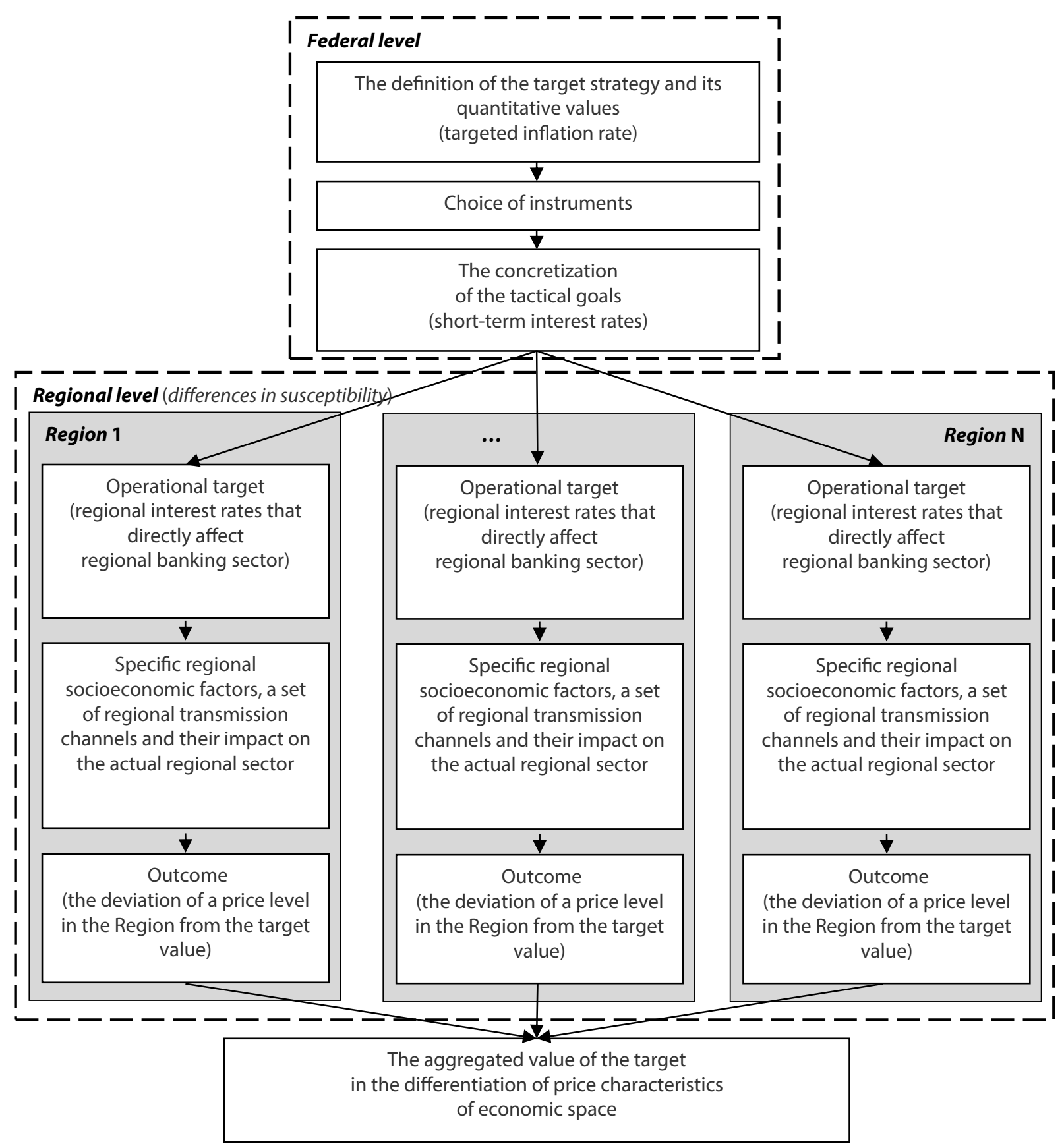

Fig. 1. Components of price stabilization policy mechanism

parameters of the money market, determining the impact of implemented price stabilization measures in the achievement of the target values of the general price increase, adjustment of the Central Bank's actions if needed. Such a set of regulatory actions can be explained with the lack of federal tools that can directly influence regional price levels, which initially have a significant variation in Russia (from 3.7\% in the Republic of Ingushetia to 9.5\% in the Magadan region in 2013 years). The Russian inflation targeting policy is made through the Central Bank of Russia that changes its shortterm interest rates. The variation of parameters in the economic space (GRP price forming in differ- ent territories) depends primarily on the efficiency of the transmission mechanism that convert decisions form the federal level to the regional and which is able to strengthen or settle the impact of monetary control.

Taking the above into consideration, regional component of stabilization policy should include those transmission mechanisms ("channels") that can define the different susceptibility of the regulatory impact of the federal center. There are a number of "channels" of transmission of the Central Bank on the regional economy, namely the welfare and its inflation expectations, business investment, lending activity of households and 


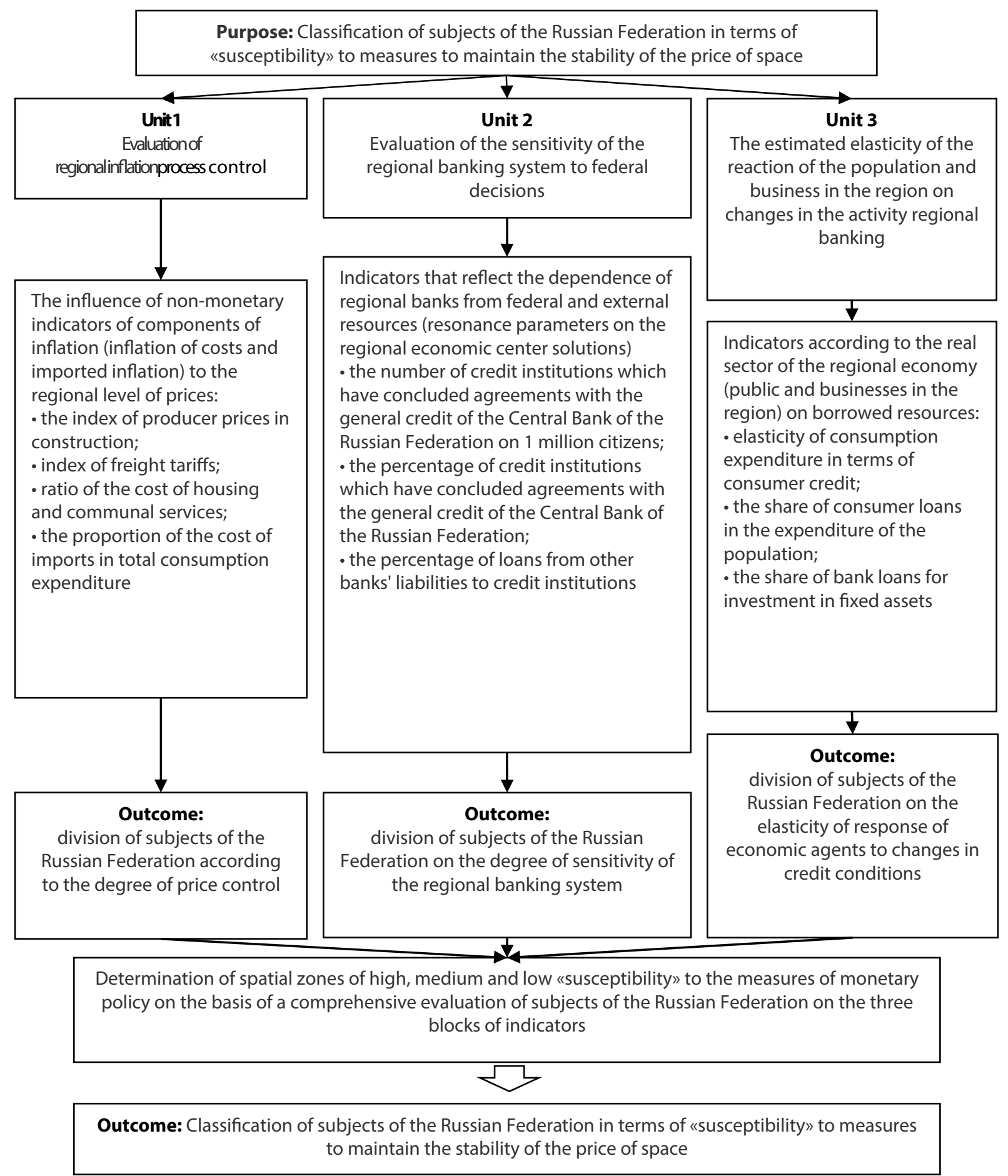

Fig. 2. Classification approach on regions of the Russian Federation by "Susceptibility" to measures to maintain price stability

businesses in the region, etc. Our understanding of the link between the federal and regional components in the mechanism of price stabilization background in Russia is formalized in Figure 1.

The identification of two main components of price stabilization mechanism defines differentiation of federal and regional factors that determine the effectiveness of policies. At the federal level, following is crucial: 1) clear definition of target priorities and scope of the necessary measures,
2) ensuring the «transparency» of economic policy and the fixation point of the targeted parameter, 3) the existence of a mechanism of accountability for the regulator that goes off the course and 4) the formation of the relationship between the federal and regional levels of the economic system (in the case of price management - between the federal and regional banking system), 5) elimination of possible constraints (except price dependence of fiscal and debt problems) 6) stimulation of 
Table 1

Average values for group A clusters

\begin{tabular}{|c|c|c|c|c|c|c|c|c|c|}
\hline & $\begin{array}{c}\text { Number } \\
\text { of Federal } \\
\text { subjects of } \\
\text { Cluster } \\
\text { the Russian } \\
\text { Federation }\end{array}$ & $\begin{array}{c}\text { The Region's } \\
\text { expenditure on imports } \\
\text { share in the volume of } \\
\text { consumer spending, } \%\end{array}$ & \multicolumn{2}{|c|}{$\begin{array}{c}\text { Construction } \\
\text { manufacturers } \\
\text { price index }\end{array}$} & $\begin{array}{c}\text { Transportation tariff } \\
\text { index }\end{array}$ & \multicolumn{2}{|c|}{$\begin{array}{c}\text { Housing and } \\
\text { communal services } \\
\text { cost factor }\end{array}$} \\
\hline 1A & 27 & 15,79 & 1 & 105,94 & 1 & 105,98 & 1 & 1,42 & 4 \\
\hline 2A & 16 & 18,42 & 2 & 107,36 & 2 & 112,83 & 3 & 0,94 & 1 \\
\hline 3A & 15 & 31,67 & 4 & 109,34 & 3 & 106,14 & 2 & 1,04 & 2 \\
\hline 4A & 22 & 20,76 & 3 & 114,87 & 4 & 114,69 & 4 & 1,14 & 3 \\
\hline RF & 80 & 21,90 & - & 108,30 & - & 107,50 & - & 1,00 & - \\
\hline
\end{tabular}

the domestic demand, 7) presence of the governed policy to preserve the competitiveness of markets as a condition of bilateral flexibility prices.

While determining the effectiveness of stabilization policies, regional factors are less dependent on the actions of the regional government but more influenced by market conditions, which limits their possible adjustment. The susceptibility of regions to the center of politics, in our opinion, is defined by the following conditions: 1 ) the degree of control of regional price background, which is determined by the predominance of monetary inflation component, depending on the policy of the Central Bank, 2) the value of borrowed funds elasticity of the regional banking system of federal action; 3) level of lending activity of the business and consumer sectors in the region. Thus, for a price management processes in the federal economies it is vital to have the proper assessment of the susceptibility of regions to measures of monetary control, which is advisable to carry out by using for the three blocks of the indicators presented in Figure 2.

Multivariate classification of regions reveals established objective reasons for the low susceptibility or immunity to the specific subjects of the stabilization measures center of Russian Federation. In order to conduct the final assessment of the prevailing conditions and spatial comparisons between regions so called "consolidated susceptibility factor" is introduced. It allows the subjects of the Russian Federation to allocate areas of high, medium and low susceptibility zone and also to be grouped accordingly.

Block 1. In order to classify subjects of the Russian Federation on the basis of the influence of "unmanaged" background factors of regional price we used indicators that define regional structural rigidity of prices: 1) the share of expenditure on imports of consumer spending in the region; 2) the producer price index in construction; 3) an index of freight tariffs; 4) the cost of housing and communal services ratio. As a result of the cluster analysis based on data for 2012-2013 we identified four clusters of subjects (group A): the subjects of the Russian Federation with the highest relative controllability rated $1 \mathrm{~A}$ (27 subject of the Russian Federation, including Samara and Tver Oblast), regions with above-average handling - 2A (16 subjects of the Russian Federation, including the Republic of Tatarstan and Perm Oblast), 3A cluster regions (15 regions of Russia including Moscow, Chelyabinsk and Sverdlovsk Oblast) characterized by a high proportion of expenditure on imports, which in theory means low price manageability background regulator; $4 \mathrm{~A}$ cluster regions combined with the uncontrolled inflation (22 subjects of the Russian Federation, including Tyumen and Kurgan region). Average values and rankings of the first block are shown in Table 1.

Block 2. The following classification of subjects of the Russian Federation was identified on the basis of regional banking systems depending on external resources and sensitivity to stabilization measures center which was conducted using the following indicators: 1) the number of regional credit organizations which have concluded agreements with the general credit to Central Bank of Russia; 2) the proportion of such organizations in the total number of banks; 3) the share of loans received from other banks on the liabilities of credit institutions registered in the region. Cluster analysis identified five types of regions (group B). High sensitivity of the banking sector characterized $1 \mathrm{~B}$ regions (25 regions of Russia, including Moscow, Sverdlovsk and Chelyabinsk Oblast). Above average sensitivity - 2B (20 subjects of the Russian Federation, including Novosibirsk and Tyumen Oblast). Regions with average sensitivity - 3B (10 subjects of the Russian Federation, including St. Petersburg and Rostov Oblast). Regions with below average sensitivity - 4B (17 subjects of the Russian Federation, including Moscow and Leningrad Oblast). Low $-5 \mathrm{~B}$ (8 subjects of the Russian Federation, including Ingushetia and 
Average values for clusters of group B

\begin{tabular}{|c|c|c|c|c|c|c|c|}
\hline \multirow{2}{*}{ Cluster } & $\begin{array}{c}\text { Number } \\
\text { of Federal } \\
\text { subjects of } \\
\text { the Russian } \\
\text { Federation }\end{array}$ & $\begin{array}{c}\text { Number of regional credit } \\
\text { organizations which have } \\
\text { credit agreements with } \\
\text { the with the Central Bank } \\
\text { of Russia (per 1 million } \\
\text { people) }\end{array}$ & $\begin{array}{c}\text { Share of credit institutions } \\
\text { that have entered into loan } \\
\text { agreements with the Central } \\
\text { Bank of Russia out of the total } \\
\text { number of credit institutions } \\
\text { in the region, \% }\end{array}$ & $\begin{array}{c}\text { The share of loans } \\
\text { received from other } \\
\text { banks in all the liabilities } \\
\text { of credit institutions } \\
\text { registered in the region, } \\
\text { \% }\end{array}$ \\
\cline { 3 - 9 } & Value & Ranking & Value & Ranking & Value & Ranking \\
\hline 1B & 25 & 5,26 & 1 & 92,78 & 1 & 4,98 & 2 \\
\hline 2B & 20 & 4,37 & 2 & 74,19 & 2 & 1,49 & 3 \\
\hline 3B & 10 & 2,16 & 3 & 55,08 & 4 & 6,62 & 1 \\
\hline 4B & 17 & 1,64 & 4 & 59,76 & 3 & 0,34 & 4 \\
\hline 5B & 8 & 0,05 & 5 & 0,87 & 5 & 0,31 & 5 \\
\hline RF & 80 & 4,20 & - & 68,34 & - & 3,17 & - \\
\hline
\end{tabular}

Table 3

Average values for clusters of group C

\begin{tabular}{|c|c|c|c|c|c|c|c|}
\hline \multirow{2}{*}{ Cluster } & $\begin{array}{c}\text { Number of } \\
\text { Federal subjects } \\
\text { of Russian } \\
\text { Federation }\end{array}$ & \multicolumn{2}{|c|}{$\begin{array}{c}\text { Elasticity of consumer } \\
\text { spending in terms of } \\
\text { consumer loans in the } \\
\text { region }\end{array}$} & $\begin{array}{c}\text { The share of consumer } \\
\text { loans in the expenditure } \\
\text { of the population of the } \\
\text { region, \% }\end{array}$ & \multicolumn{2}{|c|}{$\begin{array}{c}\text { The share of bank loans } \\
\text { to investment firms in the } \\
\text { region's fixed capital, \% }\end{array}$} \\
\cline { 3 - 9 } & Value & Ranking & Value & Ranking & Value & Ranking \\
\hline 1C & 13 & 1,011 & 1 & 17,36 & 2 & 21,07 & 1 \\
\hline 2C & 21 & 1,001 & 2 & 19,87 & 1 & 6,79 & 4 \\
\hline 3C & 24 & 0,698 & 3 & 12,45 & 3 & 6,64 & 3 \\
\hline 4C & 22 & 0,418 & 4 & 10,32 & 4 & 10,14 & 2 \\
\hline RF & 80 & 0,769 & - & 14,35 & - & 8,40 & - \\
\hline
\end{tabular}

Arkhangelsk Oblast). Average values of the second block are shown in Table 2.

Block 3. The following indicators were used to group the regions in accordance with the reaction of the population and businesses in the region to change in the lending activity of banks subject of Russia (an adaptation of the real sector to the use of stabilization policy instruments): 1) the elasticity of consumer spending in terms of credit; 2 ) the share of consumer loans in household expenditures; 3) the proportion of bank loans for investment. Cluster 1C (13 subjects of the Russian Federation, including the Tyumen and Sverdlovsk Oblast is characterized by significant activity in the use of borrowed funds while cluster 2C (21 subjects of the Russian Federation, including Republic of Tatarstan, Novosibirsk and Chelyabinsk Oblast) is characterized by more elastic reaction of the population on loan modifications. Cluster 3C (24 subjects of the Russian Federation, including Kurgan and Ulyanovsk Oblast) is determined by the average values of the comparison parameters. Cluster $4 \mathrm{C}$ includes regions with a weak reaction of the population to change of the terms of borrowed resources (22 subjects of the Russian Federation, including the Republic of Bashkortostan, Moscow,
St. Petersburg). Values and rankings of the third block are shown in Table 3.

Aggregation of the multivariate classification results allowed to offer a quantitative assessment of spatial differences in the conditions of stabilization policy implementation or so called "consolidated susceptibility factor" in the region, which was defined for each subject of the Russian Federation on the basis of the amount of value ratings assigned in accordance with the ownership of the region to certain clusters in three areas of classification (Table 4).

Regional "consolidated susceptibility factor" is a factor range from 0 to 10 indicates the relative "sensitivity" of the Russian Federation's subject to federal measures of control of the domestic price background and allows to compare regions by "sensitivity" in terms of higher/lower than in other regions or higher/lower than the Russian economy as a whole. Final calculations of "composite susceptibility factor" and the distribution of the subjects of the Russian Federation in accordance with their areas of "high", "medium", "low" susceptibility or "inert zone" are shown in Table 5.

The proposed classification allows us to identify the spatial conditions for the implementa- 
“Consolidated susceptibility factor" calculation method

Table 4

\begin{tabular}{|c|c|c|c|c|c|}
\hline $\begin{array}{c}\text { Block 1. } \\
\begin{array}{c}\text { Regional inflation process } \\
\text { controllability }\end{array}\end{array}$ & \multicolumn{2}{c|}{$\begin{array}{c}\text { Block 2. } \\
\text { regional banking dependence } \\
\text { system from external resources }\end{array}$} & $\begin{array}{c}\text { Block 3. } \\
\text { Population elasticity and behavioral } \\
\text { responses of firms in the region to } \\
\text { change the banking activity }\end{array}$ \\
\hline Cluster & Score & Cluster & Score & Cluster & Score \\
\hline $1 \mathrm{~A}$ & 3 & $1 \mathrm{~B}$ & 4 & $1 \mathrm{C}$ & 3 \\
\hline $2 \mathrm{~A}$ & 2 & 2B & 3 & $2 \mathrm{C}$ & 2 \\
\hline $3 \mathrm{~A}$ & 1 & $3 \mathrm{~B}$ & 2 & $3 \mathrm{C}$ & 1 \\
\hline $4 \mathrm{~A}$ & 0 & $4 \mathrm{~B}$ & 1 & $4 \mathrm{C}$ & \\
\hline- & - & $5 \mathrm{~B}$ & 0 & - & 0 \\
\hline
\end{tabular}

Table 5

Classification of regions by "susceptibility" to measures of center management stability domestic price level in Russia

\begin{tabular}{|c|c|c|}
\hline Susceptibility degree & $\begin{array}{l}\text { Consolidated } \\
\text { susceptibility factor }\end{array}$ & Federal subjects of Russia \\
\hline \multirow{3}{*}{$\begin{array}{l}\text { "High susceptibility" } \\
\text { (11 federal subjects } \\
\text { that generate } 14.3 \text { of } \\
\text { Russian GDP) }\end{array}$} & 10 & - \\
\hline & 9 & Altai Krai, Irkutsk Oblast \\
\hline & 8 & $\begin{array}{l}\text { Komi Republic, Republic of Khakassia, Perm Oblast, Lipetsk Oblast, } \\
\text { Nizhny Novgorod Oblast, Novosibirsk Oblast, Samara Oblast, } \\
\text { Saratov Oblast, Sverdlovsk Oblast }\end{array}$ \\
\hline \multirow{2}{*}{$\begin{array}{l}\text { "Average susceptibility" } \\
\text { ( } 30 \text { federal subjects } \\
\text { that generate } 30.8 \% \text { of } \\
\text { Russian GDP) }\end{array}$} & 7 & $\begin{array}{l}\text { Republic of Adygea, Altai Republic, Republic of Karelia, Republic } \\
\text { of Mordovia, Republic of Sakha (Yakutia) Republic of Tatarstan, } \\
\text { Republic of Tuva, Udmurt Republic, Vologda Oblast, Kaluga Oblast, } \\
\text { Kirov Oblast, Kostroma Oblast, Magadan Oblast, Ryazan Oblast, } \\
\text { Tambov Oblast, Tyumen Oblast, Chelyabinsk Oblast }\end{array}$ \\
\hline & 6 & $\begin{array}{l}\text { Kabardino-Balkar Republic, Karachai-Cherkess Republic, Republic } \\
\text { of Bashkortostan, Republic of Buryatia, Republic of Mari El, } \\
\text { Chuvashia Republic, Krasnodar Krai, Krasnoyarsk Krai, Amur } \\
\text { Oblast, Volgograd Oblast, Orel Oblast, Smolensk Oblast, Tula Oblast }\end{array}$ \\
\hline \multirow{2}{*}{$\begin{array}{l}\text { "Low Susceptibility" } \\
\text { ( } 26 \text { federal subjects that } \\
\text { generate } 43.4 \% \text { GDP of } \\
\text { Russian Federation) }\end{array}$} & 5 & $\begin{array}{l}\text { Republic of North Ossetia, Trans-Baikal Krai, Stavropol Krai, } \\
\text { Belgorod Oblast, Ivanovo Oblast, Kemerovo Oblast, Kursk Oblast, } \\
\text { Novgorod Oblast, Omsk Oblast, Ulyanovsk Oblast, Moscow, St. } \\
\text { Petersburg }\end{array}$ \\
\hline & 4 & $\begin{array}{l}\text { Republic of Kalmykia, Kamchatka Krai, Primorsky Krai, } \\
\text { Arkhangelsk Oblast, Vladimir Oblast, Kaliningrad Oblast, Kurgan } \\
\text { Oblast, Orenburg Oblast, Penza Oblast, Rostov Oblast, Sakhalin } \\
\text { Oblast, Tver Oblast, Yaroslavl Oblast, Jewish Autonomous Oblast }\end{array}$ \\
\hline \multirow{4}{*}{$\begin{array}{l}\text { "Inert zone" ( } 13 \text { federal } \\
\text { subjects that generate } \\
11.5 \text { " GDP of Russian } \\
\text { Federation) }\end{array}$} & 3 & $\begin{array}{l}\text { Khabarovsk Krai, Astrakhan Oblast, Moscow Oblast, Murmansk } \\
\text { Oblast, Tomsk Oblast, Chukotka Autonomous District }\end{array}$ \\
\hline & 2 & $\begin{array}{l}\text { Republic of Ingushetia, Chechen Republic, Bryansk Oblast, } \\
\text { Voronezh Oblast, Leningrad Oblast, Pskov Oblast }\end{array}$ \\
\hline & 1 & Republic of Dagestan \\
\hline & 0 & - \\
\hline
\end{tabular}

tion of stabilization measures, in particular, the fact that the subjects of the Russian Federation "high susceptibility" (coefficient $-8-10$ ) have sufficiently managed pricing pattern as well as the elastic response of the regional banking system and the real sector. That means that the policy conditions in the area of localization of this group of subjects potentially determine the possibility of achieving targets. "The average suscepti- bility "regions (6-7) associated with the presence of "barriers" in one of the evaluated areas (specific in the context of the each specific subjects of the Federation), hindering the achievement of the desired values. For instance, in the case of the Chelyabinsk region such a barrier is the region's high dependence on imported products, in Yakutia - conservatism of the population in terms of consumer credit and reference to self-financing in- 
vestment projects. Regions with "low susceptibility" (4-5) are limited to two directions of the evaluated areas. For example, Moscow is characterized by low controllability of the price process because the impact of cost inflation, high dependence on imports, etc. "Inert zone" $(0-3)$ subjects of the Russian Federation have the situation that is related to the presence of a set of conditions , thus blocking the response of the regional economy on regulatory action center (poor development of regional infrastructure credit, the imbalance between the real economy and the financial sector and the conservative culture of consumption). Presence of Moscow and Leningrad regions in this area can be explained by the high concentration of credit resources and infrastructure in the cities of such federal significance, and presence of Resp. Dagestan and the Chechen Resp. is due to extremely low level of socio-economic development of the territory. Regions with low susceptibility and inert zone are not resistant to the control action center.

For a more complete account of the unique features of the stabilization policy on the federal level as well as to be able to quantify the regional socio-economic impact of monetary policy it is necessary to do the following: 1) analyze the performance of the regional transmission channels on the basis of economic and mathematical modeling of price background of the Russian Federation; 2) conduct regression analysis of the population' consumption on the regional level, in conjunction of how consumer spending in influenced by wealth; 3) verify that those regional channels of interest rates and bank lending are actually working.

Simultaneous consideration of regional factors of susceptibility and performance testing of the transmission channels of monetary policy in each of the constituent entities allow us to estimate the spatial impact of the stabilization policy of the federal center. It also allows us to predict the impact of macroeconomic policies at the federal level (aggregate measure of consumer price growth in the Russian Federation) and at the level of regional socio- economic subsystems (regional consumer price indices, indicators of heterogeneity of economic space of Russia). The authors study conducted suggest that there are significant regional differences in the results of the stabilization measures and susceptibility among regions, hence the need for the development of conceptual approaches to the formation of stabilization policy in the federal countries in terms of the principles of coordination of federal and regional measures of performance indicators of stabilization policy.
Monitoring the results of anti-inflation policy in the economic space requires an objective assessment, in connection with what is expedient calculation of the "effect of stabilization measures" indicator, which is adapted from the indicator "social costs" - $L_{i}$, which characterizes the spatial effectiveness of policies to stabilize the domestic level prices in a federal state [14].

$$
L_{i}=\left(\hat{P}_{i}-\hat{P}_{i}^{*}\right)^{2}+\left(\hat{Y}_{i}-\hat{Y}_{i}^{*}\right)^{2},
$$

where $L_{i}$ - the estimate of the effect of stabilization policy in the region $i ; \hat{P}_{i}-$ the actual rate of increase in prices; $\hat{P}_{i}^{*}$ - a potential growth rate of prices; $\hat{Y}_{i}$ - the actual growth rate of real gross regional product; $\hat{Y}_{i}^{*}$ - the potential growth rate of real gross regional product.

The potential growth rate of consumer prices in the region is presented as the average longterm stable growth rate and is determined by a combination of regional factors on the basis of the regression model, the increase in consumer prices and the funds given by the regulator as a target reference of stabilization policy. In this case, the potential growth rate takes into account not only the regional specificity and stable long-term price movements in the subject of the Russian Federation, but also a change the national policy. To assess the GRP gap as a potential level of use purified (independent from random fluctuations) Hodrick-Prescott long-term value growth rate of real GRP [12].

In the event the policy of price stabilization was effective (the actual growth rate of the consumer price equal to the potential), and its implementation does not affect the amount of GRP, the value of the index effect is zero. The stronger the actual performance deviates from the potential (regardless of the sign of deviation), the less effective stabilization measures the center and above the unwanted consequences of the policy.

The use of this index allows to estimate not only the "direct" feedback to the center of the region in the form of a deviation of actual inflation from the policy orientations of the target values, but also "interface" the results of price stability as the change of the rate of economic growth, which is of particular importance for the Russian economy. Stabilization measures effect that's calculated by regions showed that the subjects of the Russian Federation is characterized by high susceptibility to stabilization policy, and there is a higher performance compared with regions resistant to the regulatory actions of the monetary authorities. Therefore, it is critical to have a mandatory coordination of federal and regional authorities, build- 


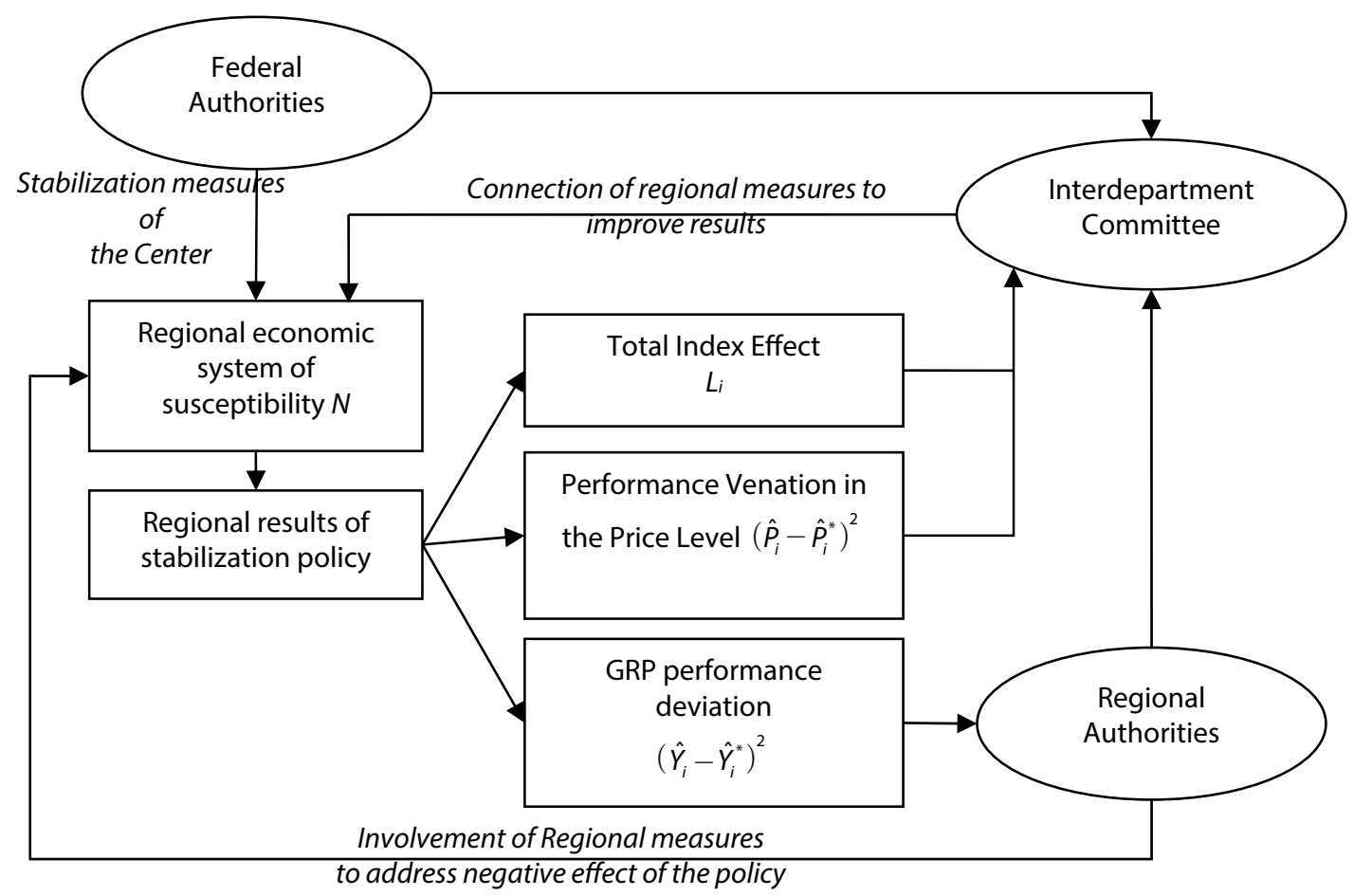

Fig. 3. Interaction between the center and the region $(N)$ while implementing the policy of price stabilization

ing inter-side of the Central Bank of Russia and the Ministry of Economic Development. The main functions of the Commission are: 1) training and examination regional laws drafts and other legal acts aimed to address the negative socio-economic impacts of the federal anti-inflation and monetary policy; 2) preparation of proposals for improving the interaction between $f$ the regional banking system and business and population, as well as development of a competitive environment in the banking sector in the region and improvement of the population's financial education; 3) monitoring, analysis and assessment of the regional econ- omy and the impact of price stabilization policy. The scheme of interaction between federal and regional authorities in the monitoring indicators of the effects of stabilization measures is presented in Figure 3.

In our opinion, the application of theory and outcome indicators will take into account the heterogeneity of economic space of Russia and build a system of coordination of interaction between the federal center and the regions, ensuring the effectiveness of stabilization policies and non-inflationary growth in Russia.

\section{References}

1. Aleksandrova Yu. L., Demchenko O. S. (2012). Problemy formirovaniya i realizatsii stabilizatsionnoy politiki [Problems of development and realization of stabilization policy]. Problemy sovremennoy ekonomiki [Problems of modern economy], 3, 99-102.

2. Baranov S. V., Skufina T. P. (2013). O metodakh issledovaniya mezhregionalnoy differentsiatsii [On methods of the interregional differentiation research]. Fundamentalnyye issledovaniya [Basic research], 10(7), 1495-1499.

3. Drobyshevskiy S. M., Sinelnikov-Murylev S. G. (2012). Makroekonomicheskie predposylki realizatsii novoy model rosta [Macroeconomic preconditions of realization of the new growth model]. Voprosy ekonomiki [Questions of Economics], 9, 4-24.

4. Merzlyaev S. A. (2011). Sravnenie rezhimov denezhno-kreditnoy politiki v eksport orientirovannoy ekonomike [Comparison of procedure of a monetary policy in export oriented economy]. Dengi i credit [Money and credit], 12, 45-57.

5. Moiseyev S. R. (2010). Modernizatsiya denezhno-kreditnoy politiki Banka Rossii dlya perekhoda k targetirovaniyu inflyatsii [Modernization of a monetary policy of the Bank of Russia for transition to inflation targeting]. Bankovskoye delo [Banking], 1, 28-34.

6. Moiseyev S. R. (2009). Politika valyutnogo kursa i politicheskiy vybor Rossii [Policy of an exchange rate and political choice of Russia]. Bankovskoye delo [Banking], 3, 32-40.

7. Orekhova Ye. A. (2008). Vliyanie kharakteristik i svoystv ekonomicheskogo prostranstva na razvitie territory [Influence of characteristics and properties of economic space on territory development]. Regionalnya ekonomika: teoriya i praktika [Regional economy: theory and practice], 10, 19-23.

8. Sukharev A. N. (2010). Stabilizatsionnyy finansovyy mechanism sovremennykh gosudarstv: teoriya, praktika i perspective [Stabilization financial mechanism of the modern states: theory, practice and prospects]. Finansovaya analitika [Financial analytics], 11, 40-46. 
9. Ekova V. A. (2012). Teoretiko-metodologicheskie podkhody $\mathrm{k}$ issledovaniyu prostranstvennoy neodnorodnosti sotsialno-ekonomicheskogo razvitiya regiona [Theoretical and methodological approaches to the research of spatial heterogeneity of socio-economic development of a region]. Izvestiya Saratovskogo universiteta. Seriya: ekonomika, upravlenie, pravo [News of the Saratov university. Series: economy, management, right], 3, 13-16.

10. Antonyuk V. S., Vansovich E. R. (2012). Assessment of regional industry-specific shifts. Economy of Region, 1, 161-169.

11. Blanchard O. (2007). Macroeconomics. Pearson Education, 624.

12. Hodrick R., Prescott E. (1997). Postwar U. S. Business Cycles: An Empirical Investigation. Journal of Money, Credit, and Banking, 1-16.

13. Maslov A. I. (2012). Inflationary handicap of the monetary transmission mechanism: evidence from Russia. Journal of Economic Regulation, 4, 109-124.

14. Sachs J., LarrainF. (1993). Macroeconomics in the Global Economy. Prentice Hall, 778.

15. Tatarkin A. I., Animitsa E. G. (2012). Formation of paradigmatic theory of regional economy. Economy of Region, 3, $22-32$.

16. Tinbergen J. (1978). Economic policy: Principles and Design. Amsterdam, 276.

17. Welfens P. (2008). Digital integration, growth and rational regulation. Springer, 186.

\section{Information about the authors}

Danilova Irina Valentinovna (Chelyabinsk, Russia) - Doctor of Economics, Professor at the Chair for Economic Theory, World and Regional Economics, South Ural State University (National Research University) (76, Lenina av., Chelyabinsk, 454080, Russia, e-mail: irdanilova@yandex.ru).

Rezepin Aleksandr Vladimirovich (Chelyabinsk, Russia) - PhD in Economics, Senior Lecturer at the Chair for Economic Theory, World and Regional Economics, South Ural State University (National Research University) (76, Lenina av., Chelyabinsk, 454080, Russia, e-mail: rezepin.av@mail.ru). 